\title{
PENGEMBANGAN MODEL PENYULUHAN KESEHATAN PADA KELUARGA UNTUK MENURUNKAN ANGKA KEJADIAN KEKERASAN PADA ANAK DI KABUPATEN BOGOR
}

\author{
Sulha, Nur Aisah Amini, Aryo Gagat Rakasiwi. \\ sulha217@gmail.com \\ Mahasiswa Fakultas Ilmu Kesehatan
}

\begin{abstract}
ABSTRAK
Kekerasan anak merupakan fenomena sosial yang cenderung meningkat, baik secara kuantitatif maupun kualitatif pada dasawarsa terakhir ini, Institusi pemerintah maupun swasta yang bergerak di bidang perlindungan anak, secara berkala menyajikan angka kekerasan yang semakin meningkat. Penyuluhan kesehatan merupakan salah satu upaya untuk menambah pengetahuan dan kemampuan seseorang melalui tekhnik praktek belajar atau instruksi yang bertujuan untuk mengubah atau mempengaruhi perilaku manusia baik secara individu, kelompok maupun masyarakat agar dapat lebih mandiri dalam mencapai tujuan hidup sehat. Faktor terjadinya kekerasan pada anak di sebabkan karena faktor orang tua/kelurga, faktor lingkungan sosial/komunitas dan faktor anak sendiri, untuk itu pengembangan penyuluhan kesehatan yang akan di lakukan ini bertujuan untuk mengubah perilaku anak ataupun perlakuan terhadap anak sehingga tercapainya tumbuh kembang anah secara optimal. Contoh konkret dari permasalahan di atas yaitu model penyuluhan kesehatan yang diberikan kepada keluarga masih sangat jarang yang menyinggung tentang bagaimana perilaku perlakuan orang dewasa yang benar terhadap anak dalam hal psikis dan mental anak.
\end{abstract}

\section{Kata Kunci: Kekerasan pada Anak, Keluarga, Penyuluhan Kesehatan.}

\section{PENDAHULUAN}

\section{Latar Belakang}

Penyuluhan kesehatan adalah penambahan pengetahuan dan kemampuan seseorang melalui tekhnik praktek belajar atau instruksi dengan tujuan mengubah atau mempengaruhi perilaku manusia secara individu, kelompok maupun masyarakat untuk dapat lebih mandiri untuk mencapai tujuan hidup sehat (Depkes 2002). Penyuluhan kesehatan adalah gabungan berbagai kegiatan dan kesempatan yang berlandaskan prinsip-prinsip belajar untuk mencapai suatu keadaan dimana individu, keluarga, kelompok, atau masyarakat secara keseluruhan ingin hidup sehat, tahu bagaimana caranya dan melakukan apa yang bisa dilakukan, secara perseorangan maupun secara kelompok dengan meminta pertolongan (Effendy, 2003).

Tujuan penyuluhan kesehatan sebagaimana yang telah dijelaskan secara jelas yaitu untuk tercapainya perubahan perilaku individu, keluarga dan masyarakat dalam membina dan memelihara perilaku yang sesuai dengan konsep hidup sehat baik fisik, mental, sosial sehingga dapat menurunkan angka kesakitan dan kematian. Sebagai contoh yaitu dampak dari pola asuh keluarga 
terhadap proses pertumbuhan dan perkembangan anak.

Peraturan Menteri Negara PPPA

No. 2 Tahun 2011, kekerasan pada anak dapat diartikan sebagai setiap perbuatan terhadap anak yang berakibat timbulnya kesengsaraan atau penderitaan secara psikologis, termasuk penelantaran dan perlakuan buruk yang mengancam integritas tubuh dan merendahkan martabat anak yang dilakukan oleh pihakpihak yang seharusnya bertanggung jawab atas anak tersebut. Menurut Rusmil (2004), menjelaskan bahwa penyebab atau risiko terjadinya kekerasan dan penelentaraan terhadap anak dibagi ke dalam tiga faktor,yaitu faktor orang tua/ keluaraga, faktor lingkungan sosial/komunitas dan faktor anak sendiri.

Kekerasan anak merupakan
fenomena sosial yang cenderung meningkat, baik secara kuantitatif maupun kualitatifnya pada dasawarsa terakhir ini. Institusi pemerintah maupun swasta yang bergerak di bidang perlindungan anak, secara berkala menyajikan angka kekerasan anak yang cenderung meningkat. Namun demikian, angka-angka yang dipublikasi tersebut masih sebatas kasus yang dilaporkan atau yang memperoleh pelayanan di Rumah Sakit, Puskesmas, KPAI, kepolisian dan lembaga pelayanan dan perlindungan anak. Sedangkan angka-angka yang sesungguhnya masih sulit ditemukan, karena kekerasan anak ini merupakan fenomena gunung es. Banyak kasus kekerasan anak yang tidak terungkap ke publik dengan berbagai alasan.

\section{Faktor-faktor Terjadinya Angka Kekerasan pada Anak}

Pemicu kekerasan pada anak bisa terjadi karena berbagai faktor diantaranya adalah: (1) Kekerasan dalam rumah tangga, yang menjadikan anak sebagai sasaran kemarahan ayah, ibu dan asaudara yang lainnya; (2) Disfungsi keluarga, yang mengakibatkan orang tua tidak bisa melaksanakan peran sebagaimana mestinya, seperti ayah yang tidak bisa berperan sebagai pemimpin keluarga, ibu yang tidak bisa berperan sebagai sosok yang membimbing dan menyayangi anak; (3) Kondisi ekonomi keluarga; (4) Anak memiliki cacat tubuh, retardasi mental, gangguan tingkah laku, autisme, memiliki tempramental lemah, sehingga hanya bergantung pada orang tua; (5) Keluarga pecah (broken home) akibat perceraian, ketiadaan ibu atau ayah dalam jangka panjang; (6) Keluarga yang belum matang secara psikologis, ketidak mampuan mendidik anak, harapan orang tua yang tidak realistis terhadap anak, an ak lahir diluar nikah; (7) Gangguan mental pada salah satu orang tua (8) Orang tua yang dulu sering mendapatkan perlakuan kekerasan, sering memperlakukan anaknya dengan perlakuan yang sama. (Nurdin Widodo, $2014: 9$ )

Oleh karena itu, penulis termotivasi untuk melakukan penelitian guna mengembangkan model penyuluhan kesehatan pada keluarga untuk mengurangi angka kekerasan pada anak. Dengan pembatasan masalah bahwa penelitian ini dilakukan untuk mengembangkan penyuluhan kesehatan pada keluarga untuk mengurangi angka kejadian kekerasan pada anak. 


\section{METODE PENGABDIAN}

\section{Tahapan Penelitian}

Penelitian ini adalah jenis penelitian kuasi eksperimen dengan model R\&D. Dalam penelitian ini, yang menjadi sumber data/ populasi adalah keluarga di Kabupaten Bogor. Sampel dalam penelitian ini akan diambil sebanyak 10 posyandu dengan kriteria unggul, sedang, dan kurang. Pengambilan 10 posyandu tersebut menggunakan metode stratified-cluster random sampling yang didasarkan pada heterogenitas melalui pengumpulan data dari Dinas Kesehatan Bogor. Penelitian dilakukan terbatas pada keluarga yang ada di kabupaten bogor dengan sampel keluarga yang memiliki anak. Tahapantahapan dari penelitian ini adalah:

a. Studi pendahuluan yang meliputi a) studi kepustakaan terkait teori dan konsep model penyuluhan kesehatan serta pendekatan, strategi, metode dan tehnik penyuluhan kesehatan yang relevan dengan model tersebut; b) survei lapangan yang meliputi penghimpunan data untuk perencanaan dan pelaksanaan penyuluhan kesehatan di puskesmas, melalui tehnik observasi dan studi dokumenter, c) penyusunan draf model awal oleh tim peneliti dengan arahan dari dosen pembimbing.

b. Pengembangan dan penyempurnaan draf model awal melalui uji coba terbatas dan uji coba luas. Uji coba terbatas dilakukan pada penyuluhan kesehatan di 1 puskesmas, kategori sedang dan dilanjutkan dengan evaluasi untuk mengetahui tingkat efektivitas model yang telah disusun dan dikembangkannya. Selanjutnya model yang telah disempurnakan diujikan kembali pada penyuluhan kesehatan di 3 puskesmas sampel dengan kategori unggul, sedang dan kurang. Hasil pengamatan dan data yang diperoleh dari uji coba luas ini selanjutnya melalui evaluasi dan penyempurnaan secara terusmenerus, sehingga dinilai tidak ada kekurangan dan kelemahan lagi.

c. Pengujian keampuhan dari model penyuluhan kesehatan yang telah dihasilkan, dibandingkan dengan model penyuluhan kesehatan konvensional yang diterapkan dipuskesmas di Kabupaten Bogor. Pengujian dilakukan dengan menggunakan metode eksperimental dengan menggunakan dua kelompok sampel, yaitu kelompok eksperimen dan kelompok kontrol. Jumlah kelompok eksperimen sebanyak 3 puskesmas, dengan kategori puskesmas unggul, sedang dan baik. Kelompok kontrol memiliki jumlah dan kategori yang sama dengan kelompok eksperimen.

Sebelum pembelajaran dimulai, masing-masing keluarga diberi pretest yang sama. Setelah selesai eksperimen, lalu mereka diberi post test, dan selanjutnya diadakan analisis statistik uji perbedaan antara hasil pretest dengan post test pada kelompok eksperimen dan kelompok kontrol dalam kategori yang sama, sehingga dihasilkan kesimpulan. 
Diagram Alur Metode Penelitian

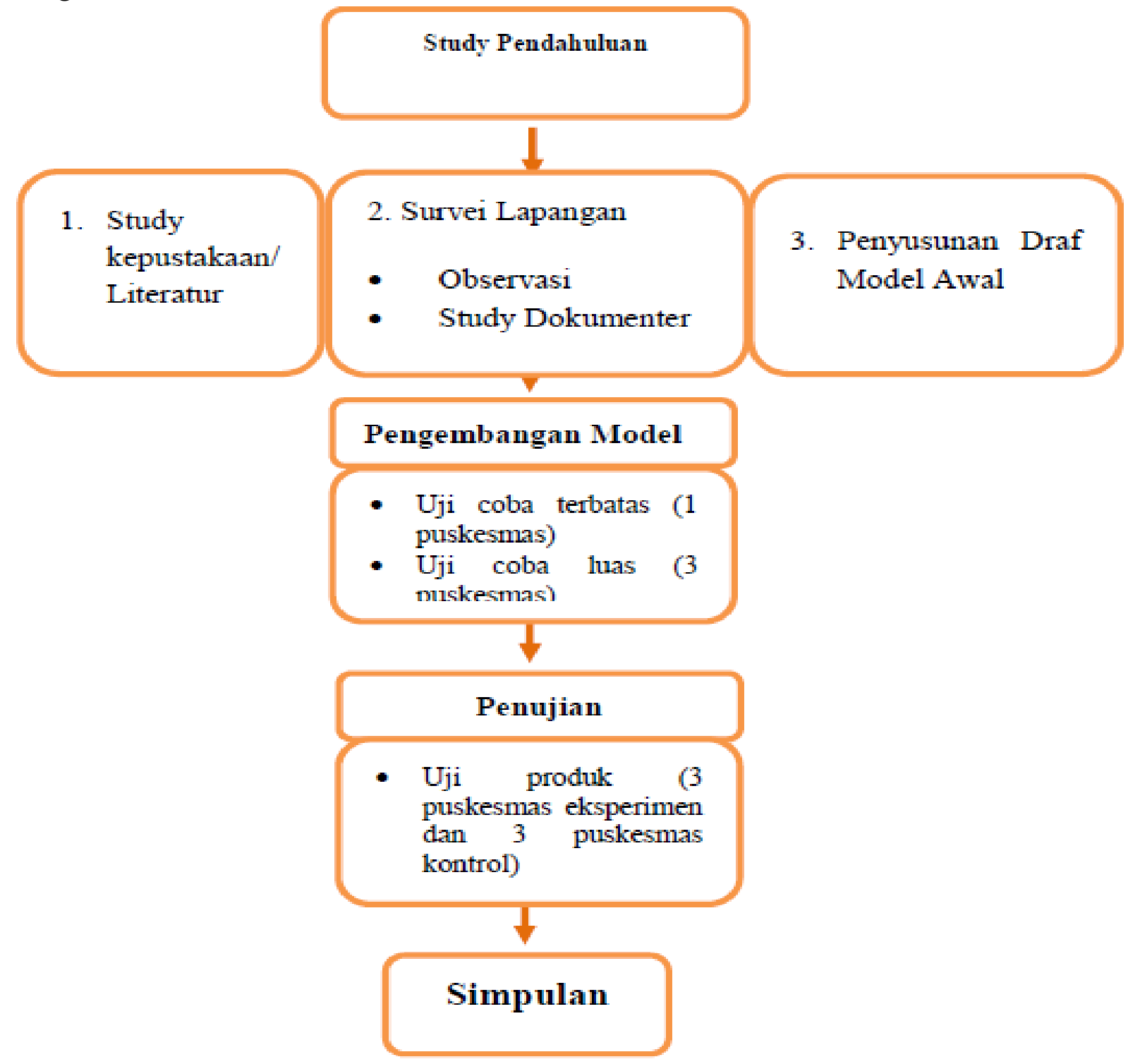

\section{Luaran Penelitian}

Luaran dari penelitian ini yaitu:

a. Diperolehnya model pengembangan penyuluhan kesehatan baru pada keluarga untuk menurunkan angka kejadian kekerasan pada anak sehingga mampu mencapai target yang di harapkan sesuai dengan UU No 23 tahun 2002 yang berbunyi upaya perlindungan anak perlu dilaksanakan sedini mungkin, yakni sejak dari janin dalam kandungan sampai anak berumur 18 tahun. Bertitik tolak dari konsepsi perlindungan anak yang utuh, menyeluruh, dan komprehensif. Serta meberika perlindungan asas sesuai dengan, nondiskriminasi, kepentingan yang terbaik bagi anak, hak untuk hidup, kelangsungan hidup, perkembangan, dan penghargaan terhadap pendapat anak. Sedangkan menurut UU No 35 tahun 2014 tentang perlindungan anak merupakan kegiatan untuk menjamin dan melindungi anak dan hak-haknya agar dapat hidup, tumbuh, berkembang dan berpartisipasi secara optimal sesuai dengan harkat dan martabat 
kemanusiaan serta mendapat perlindungan dari kekerasan dan diskriminasi.

b. Artikel atau paper pada jurnal nasional "Jurnal Kesehatan Masyarakat Terakreditasi DIKTI".

\section{Indikator Capaian yang Terukur pada} Tiap Tahapan

Indikator capaian yang terukur pada tiap tahapan yaitu sebagai berikut:

a. Pada tahap studi pendahuluan akan diperoleh draf model pengembangan penyuluhan kesehatan yang sesuai dengan kebutuhan keluarga di puskesmas karena dilandaskan dari data yang didapat dari survei lapangan dan mengacu pada dasardasar teori atau konsep yang disimpulkan dari hasil studi kepustakaan

b. Pada tahap pengembangan model akan diketahui efektivitas dari draf model penyuluhan kesehatan awal dan penyempurnaan serta pengembangan draf.

c. Pada tahap pengujian akan diperoleh produk/ hasil akhir yang berupa model penyuluhan kesehatan baru yang dapat dipertanggungjawabkan dan siap diterapkan atau digunakan di puskesmas.

\section{Tehnik Pengumpulan Data}

Pengumpulan data pada penelitian ini menggunakan tehnik test, lembar observasi dan angket.

\section{Analisis Data}

Analisis data pada penelitian ini menggunakan tehnik analisis kualitatif dan uji t. Tehnik analisis kualitatif digunakan untuk menganalisis hasil pengamatan kelas terhadap uji coba model pengembangan penyuluhan kesehatan dengan cara membandingkan antara kegiatan-kegiatan yang biasa dilakukan oleh petugas kesehatan dengan kegiatan-kegiatan yang seharusnya dilakukan petugas kesehatan pada saat implementasi model penyuluhan kesehatan. Hasil analisis ini dipakai sebagai bahan untuk melakukan revisi dan uji coba selanjutnya. Sedangkan uji t digunakan untuk menganalisis skor ratarata frekuensi kekerasan pada anak dalam aktifitas yang terjadi dalam keluarga. Tehnik ini dipakai untuk mengetahui efektifitas model penyuluhan kesehatan dengan cara menganalisis perbandingan skor perolehan antara pengetahuan dan sikap keluarga sebelum mengikuti kegiatan dengan kemampuan setelah mengikuti kegiatan. Analisis data dengan uji $\mathrm{t}$ menggunakan bantuan software SPSS 20 for windows. 


\section{REALISASI PROGRAM}

\section{Anggaran Biaya}

\begin{tabular}{|c|c|c|}
\hline No. & Jenis Pengeluaran & Biaya (Rp.) \\
\hline 1 & $\begin{array}{l}\text { Peralatan penunjang } \\
\text { Buku paket IPA SD, media pembelajaran dan } \\
\text { sewa printer serta kamera SLR, }\end{array}$ & Rp. 3.000.000 \\
\hline 2 & $\begin{array}{l}\text { Bahan habis pakai } \\
\text { Tinta print, kertas A4, fotocopy, ATK dan } \\
\text { internet data }\end{array}$ & Rp. 1.550 .000 \\
\hline 3 & $\begin{array}{l}\text { Perjalanan } \\
\text { Observasi puskesmas dan lainnya (selama } 5 \\
\text { bulan), pelaksanaan penelitian }\end{array}$ & Rp. 5.000 .000 \\
\hline 4 & $\begin{array}{l}\text { Lain-lain } \\
\text { Penggandaan laporan, seminar hasil PKM dan } \\
\text { dokumentasi }\end{array}$ & Rp. 1.580 .000 \\
\hline & Jumlah & Rp.11.130.000 \\
\hline
\end{tabular}

\section{Jadwal Kegiatan}

Berikut merupakan jadwal kegiatan:

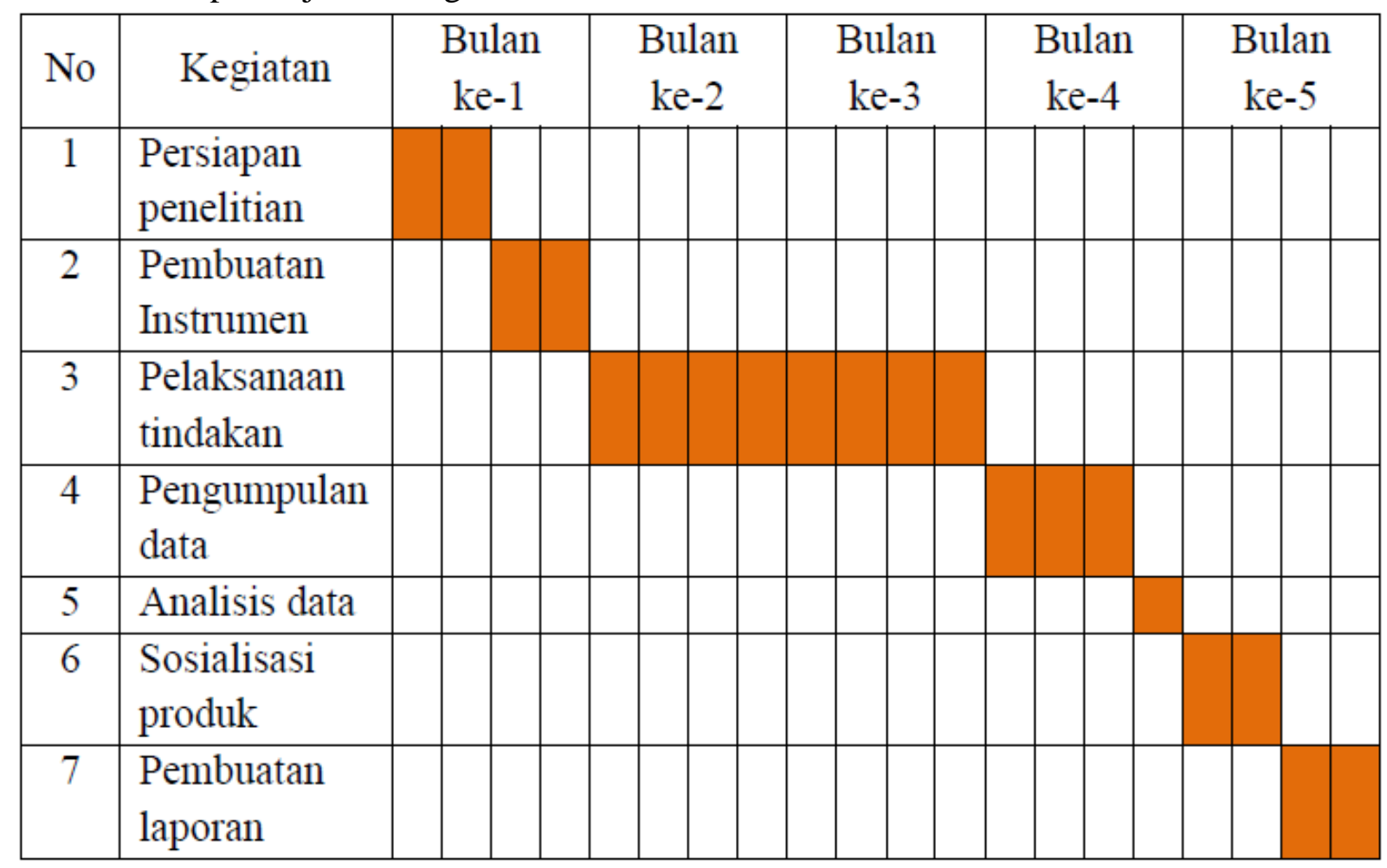




\section{KESIMPULAN}

\section{Tujuan Penelitian}

Berdasarkan rumusan masalah di atas, maka penelitian ini bertujuan khusus untuk:

a. Mengetahui hubungan atau pengaruh dari model penyuluhan kesehatan pada keluarga untuk menurunkan angka kejadian kekerasan pada anak.

b. Mengetahui dan mengembangkan model penyuluhan kesehatan pada keluarga yang sesuai dalam rangka menurunkan angka kejadian kekerasan pada anak.

\section{Urgensi Penelitian}

Keutamaan atau urgensi dari penelitian ini adalah diharapkan ditemukannya pengembangan model penyuluhan kesehatan pada keluarga yang dapat mengefektifkan upaya menurunkan angka kejadian kekerasan pada anak sehingga anak bisa tumbuh dan berkembang secara optimal, serta dapat meningkatkan status kesehatan generasi muda yang ada di tangan anak sebagai generasi penerus bangsa dan merupakan investasi sumber daya di masa yang akan datang.

\section{Temuan yang Ditargetkan}

Temuan yang ditargetkan pada penelitian ini yaitu model pengembangan penyuluhan kesehatan baru yang dapat diterapkan pada keluarga untuk menurunkan angka kejadian kekerasan pada anak yang sesuai dengan implementasi UU No 23 tahun 2002. Temuan yang dihasilkan adalah berupa metode dan media baru yang dapat dipertanggungjawabkan dan siap diaplikasikan oleh institusi-institusi yang menangani masalah kekerasan pada anak.

\section{Kontribusi terhadap Ilmu Pengetahuan Sosial Humaniora}

Kontribusi dari penelitian ini terhadap ilmu pengetahuan sosialhumaniora yaitu untuk memecahkan permasalahan sosial-humaniora terkait penurunan angka kejadian kekerasan pada anak yang sesuai dengan implementasi UU No 23 tahun 2002 yaitu tentang perlindungan anak.

\section{Luaran}

Luaran dari penelitian ini yaitu:

a. Diperolehnya model pengembangan penyuluhan kesehatan baru pada keluarga untuk menurunkan angka kejadian kekerasan pada anak sehingga mampu mencapai target yang di harapkan sesuai dengan UU No 23 tahun 2002 yang berbunyi upaya perlindungan anak perlu dilaksanakan sedini mungkin, yakni sejak dari janin dalam kandungan sampai anak berumur 18 tahun. Bertitik tolak dari konsepsi perlindungan anak yang utuh, menyeluruh, dan komprehensif. Serta meberika perlindungan asas sesuai dengan, nondiskriminasi, kepentingan yang terbaik bagi anak, hak untuk hidup, kelangsungan hidup, perkembangan, dan penghargaan terhadap pendapat anak. Sedangkan menurut UU No 35 tahun 2014 tentng perlindungan anak merupakan kegiatan untuk menjamin dan melindungi anak dan hak-haknya agar dapat hidup, tumbuh, berkembang dan berpartisipasi secara optimal sesuai dengan harkat dan martabat kemanusiaan serta 
mendapat perlindungan dari kekerasan dan diskriminasi.

b. Artikel atau paper pada jurnal nasional "Jurnal Kesehatan Masyarakat Terakreditasi DIKTI".

\section{Manfaat Penelitian}

Manfaat dari penelitian ini adalah sebagi berikut:

a. Bagi peneliti, Hasil dari penelitian ini berguna untuk menambah pengetahuan dan keterampilan peneliti mengenai model pengembangan penyuluhan kesehatan di keluarga.

b. Bagi keluarga, Hasil penelitian ini dapat memberikan wawasan dan keterampilan untuk mengaplikasikan model pengembangan penyuluhan kesehatan pada keluarga dalam mencegah peningkatan angka kejadian kekerasan pada anak sehingga dapat mencapai tujuan yang di harapkan.

c. Bagi anak, Hasil dari penelitian ini berguna untuk melindungi anak dari perilaku kekerasan, sehingga dapat tercapai pertumbuhan dan perkembangan anak secara optimal.

\section{REFERENSI}

Delany Stephanie, dkk. 2016. Melindungi Anak-Anak dari Eksploitasi Seksual dan Kekerasan dalam Situasi Bencana dan Kegawat Daruratan. Medan: ECPAT Internasional

Khusnal Ery, Irmawati. 2012. Pengaruh Penyuluhan Kesehatan Tentang Child Abuse Terhadap Pengetahuan Dan Sikap Orang
Tua Dengan Anak Usia 0-13

Tahun Di Dusun Sanggrahan

Tirtoadi Mlati Sleman

Yogyakarta. [online]. Tersedia: digilib.unisayogya.ac.id.

(Diakses 25 November 2017)

KPAI. 2017. Undang-Undang No 23 tahun 2002 tentang Perlindungan anak. Profil Komisi Perlindungan Anak Indonesia. [Online] (Diakses 25 November 2017)

Mitra Wacana. 2016. Undang-Undang No 35 tahun 2014 Tentang Perlindungan Anak. 24 November 2017.

http://mitrawacana.or.id/kebijakan /uu-n0-35-tahun-2014-tentangperlindungan-anak/

Maharani Firda Dwi. Dkk. Anak adalah Anugrah: STOP Kekerasan pada Anak. Jakarta: KOMINFO.

Pasalbessy John Dirk. 2010. Dampak Tindak Kekerasan Terhadap Perempuan dan Anak Serta Solusinya. Jurnal Sasi. Vol.16 No.3. [online].

(Diakses 26 Novemeber 2017)

Suradi. 2013. Problem dan Solusi Strategi Kekerasan Terhadap Anak. Profil Pusat Penelitian dan kesejahteraan Sosial RI. Vol.18. No.02 [online] ( Diakses 24 November 2017)

Widodo Nurdin, dkk. 2014. Perlindungan Sosial bagi Anak Korban Tindak Kekerasan. Jakarta: Puslitbangkesos RI. 